\title{
CONSERVATION EASEMENTS: Pluses ANd Pitfalls, Generally ANd For Municipalities
}

\author{
ARLENE J. KWASNIAK*
}

This article examines the role of conservation easements in Canada and their utility in protecting the natural values of land by way of restricted development. The author begins with an overview of both common law and statutory conservation easements throughout Canada with a specific focus on Alberta. Advantages and disadvantages are identified in general with regard to the use of conservation easements by municipalities. Finally, the article locates and explores the benefits of conservation easements as a proactive pre-development, and reactive post-development tool which can be used by municipalities when carrying out land use mandates.
Cet article porte sur le rôle des lois sur les servitudes écologiques au Canada et leur utilité dans la protection de la valeur naturelle de la terre pour en limiter le développement. L'auteur commence par donner un aperçu à la fois de la common law et des lois sur les servitudes écologiques au Canada en insistant essentiellement sur l'Alberta. Les avantages et les inconvénients y sont identifiés en général par rapport au recours que les municipalités font à ces lois. Enfin, l'article détermine et examine les avantages des lois sur les servitudes écologiques en tant qu'outil proactif avant le développement et réactif après le développement que les municipalités peuvent utiliser pour exécuter des mandats de mise en valeur de terres.

\section{TABLE OF CONTENTS}

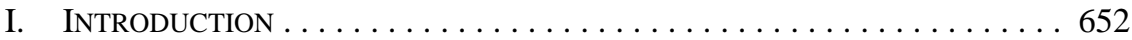

II. CONSERVATION EASEMENTS $\ldots \ldots \ldots \ldots \ldots \ldots \ldots \ldots \ldots \ldots \ldots \ldots \ldots \ldots$

A. Why CONSERVATION EASEMENT LEGISLATION EXISTS _...... 653

B. COMMON FEATURES OF CONSERVATION EASEMENTS . . . . . . . . 655

C. Conservation EASEMEnt LegisLation in AlBerta . . . . . . . . 655

III. Pluses AND Pitfalls — Generally $\ldots \ldots \ldots \ldots \ldots \ldots \ldots \ldots 6 . \ldots \ldots$

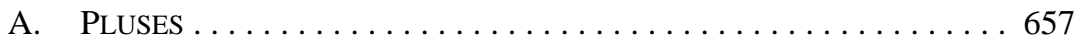

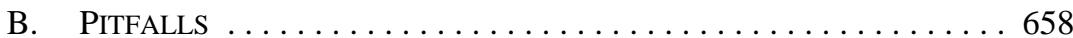

IV. Pluses And Pitfalls in Municipal Use OF

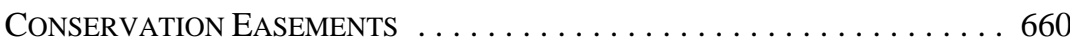

A. Pluses . . . . . . . . . . . . . . . . . . . . . . 660

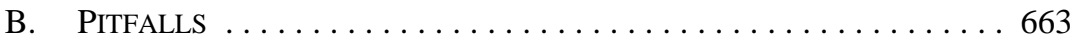

C. THe JuRisdictionAL ISSUE $\ldots \ldots \ldots \ldots \ldots \ldots \ldots \ldots \ldots \ldots 66$

V. CONSIDERATIONS FOR MUNICIPALITIES CONTEMPLATING USING CONSERVATION EASEMENTS IN LAND USE PLANNING, Subdivision, AND DEVELoPMENT PRocesses $\ldots \ldots \ldots \ldots \ldots \ldots 670$

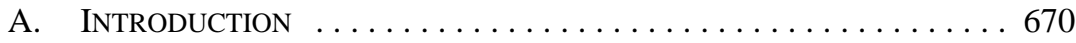

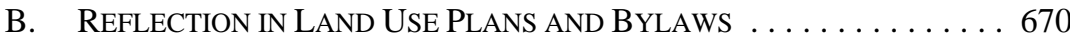

C. CONSERVATION EASEMENTS AND

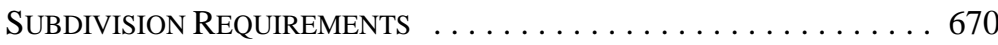

D. Modification and TERmination of

E. Holder of A Conservation EASEMENT $\ldots \ldots \ldots \ldots \ldots \ldots 672$ 
VI. Transfer of DEVElopment CREDIT PROGRAMS AND

CONSERVATION EASEMENTS AND SimILAR INSTRUMENTS . . . . . . . . 673

A. ABOUT MUNiCiPAl TRANSFER OF

Development CRedit Programs . . . . . . . . . . . . . 673

B. A ROLE FOR CONSERVATION EASEMENTS AND

SIMILAR INSTRUMENTS AND LIMITATIONS $\ldots \ldots \ldots \ldots \ldots \ldots \ldots . \ldots . \ldots 674$

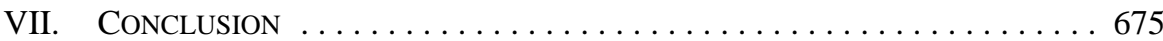

\section{INTRODUCTION}

Conservation easements are statutorily created interests in land, constituted through voluntary legal agreements, that landowners may enter into to protect the natural values of all or a part of their land by restricting development. When properly registered, conservation easements run with the land and development restrictions are enforceable in accordance with the terms of the conservation easement agreement. This article discusses the pluses and pitfalls concerning the use of conservation easements in Canada, especially for municipalities. While much of the article is applicable throughout Canada, the focus is on Alberta, with appropriate examples given from Ontario.

Part II provides an overview of conservation easements. It describes both the shortcomings of the common law to create similar legal interests and how law reform processes led to the creation of statutory conservation easements. It sets out common features of conservation easements throughout Canada and provides detailed information on Alberta conservation easements. Part III identifies and describes some pluses and pitfalls of using conservation easements.

Part IV focuses on the pluses, pitfalls, and use of conservation easements by municipalities. It demonstrates the benefits of municipal use of conservation easements both proactively (prior to subdivision or development applications) and reactively (within the subdivision and development context). It discusses whether an Alberta municipality has a legal right to use conservation easements while exercising land use planning and development functions or whether it is confined to specific legislative powers in this regard. On the basis of a statutory interpretation analysis, this section concludes that, absent legislative provisions to the contrary, an Alberta municipality may use conservation easements when carrying out land use related mandates. Although the analysis focuses on Alberta, it provides a framework for comparable analyses for other provinces.

Part V sets out considerations for municipalities contemplating using conservation easements in land use planning, subdivision, and development processes. Part VI briefly describes how conservation easements might have a limited use in transfer of development credit programs and Part VII concludes the article. 


\section{CONSERVATION EASEMENTS}

\section{A. Why CONSERVATION EASEMENT LEgISLATION EXISTS}

Contrary to the beliefs of some, the conservation movement is not a new fad. ${ }^{1}$ From time immemorial there have been humans who, as Aldo Leopold has said, cannot live without wild things. ${ }^{2}$ But, as Leopold continues, "[l]ike winds and sunsets, wild things were taken for granted until progress began to do away with them." ${ }^{3}$ To meet the challenges of "progress," landowners, whether public or private landowners, have sought ways to protect the cherished natural values of land from destruction or diminishment.

Naturalist thinkers earlier than Leopold, such as Ralph Waldo Emerson, Henry David Thoreau, George Perkins Marsh, John Muir, and John Burroughs, helped us appreciate the magnificence and the subtlety of nature in miniature to vast natural landscapes. ${ }^{4}$ Naturalist thinkers later than Leopold have helped us appreciate a vast range of intrinsic, instrumental, and systemic values of the natural environment, including life support, economic, recreational, scientific, aesthetic, genetic diversity, biological, wildlife, historical, cultural, character-building, life, and religious values. ${ }^{5}$ The works of all of these writers influence landowners, both public and private, to protect the natural values of lands. Governments enjoy a range of legislative designation tools to set aside and protect the natural values of land in the form of national, state, or provincial parks. However, until conservation easement legislation, there was little to facilitate private landowners' aspirations to protect natural land values outside of park borders.

Prior to conservation easements, private landowners had to rely on common law tools to limit uses of land. Conservation easement legislation exists because of the limitations of comparable common law interests. These interests are common law easements and common law restrictive covenants. The legal rules for creating a valid easement or restrictive covenant are complex and burdensome. Only in rare circumstances could a landowner who wants to preserve and maintain the environmental values of land fit under them. Although there are numerous reasons why, ${ }^{6}$ the primary reason is that to constitute a valid common law

Margaret Lewis, To Conserve a Heritage (Calgary: Alberta Fish \& Game Association, 1979) at ix. Aldo Leopold, A Sand County Almanac: With Essays on Conservation from Round River (New York: Oxford University Press, 1966) at xvii.

Ibid.

$4 \quad$ See e.g. Ralph Waldo Emerson, Nature: Addresses and Lectures (New York: A.L. Burt, 1849) at 5-76; Henry D. Thoreau, "Walking” (1862) 9 Atlantic Monthly 675; George P. Marsh, Man and Nature (New York: Scribner, 1865); John Muir, The Mountains of California (New York: Century, 1894) at 48-73. For a discussion on how these authors influenced the development of a nature aesthetic, see Allen Carlson \& Sheila Lintott, "Introduction: Natural Aesthetic Value and Environmentalism” in Allen Carlson \& Sheila Lintott, eds., Nature, Aesthetics, and Environmentalism: From Beauty to Duty (New York: Columbia University Press, 2008) at 1-21.

5 See Holmes Rolston III, Environmental Ethics: Duties To and Values in the Natural World (Philadelphia: Temple University Press, 1988), especially c. 1.

$6 \quad$ For a more thorough discussion of this issue see Arlene J. Kwasniak, Legal Mechanisms for Private Land Conservancy in Alberta: A Law Reform Proposal (Edmonton: Environmental Law Centre, 1991); Arlene J. Kwasniak, “Facilitating Conservation: Private Conservancy Law Reform” (1993) 31 Alta. L. Rev. 607. Briefly, the limitations and restrictions are the requirement for the existence of a dominant tenement that demonstrably benefits from restrictions (for restrictive covenants) or rights relating to (for 
easement or restrictive covenant, there must be two parcels of land, separately owned and occupied. ${ }^{7}$ With easements, the owner of one parcel of land, the "dominant tenement," is given rights to access or use some aspect of a parcel of land, called the "servient tenement." With restrictive covenants, the owner of the dominant tenement restricts the use of the servient tenement in a manner that benefits the dominant tenement. As well, there must be a demonstrable benefit to the dominant tenement from the rights or restrictions relating to the servient tenement. It would not be usual that there is an appropriate parcel to serve as a dominant tenement when a person wishes to protect land for environmental purposes. ${ }^{8}$

For years, Canadian conservation organizations and interested landowners called upon provincial governments to pass legislation that would allow landowners to protect the natural values of their land without having to transfer entire parcels, or without having to meet the stringent, cumbersome common law conditions. The organizations and individuals jealously looked beyond the Canadian border to the United States, where conservation easement legislation existed for decades. Finally, in the 1990s Canadian jurisdictions began developing conservation easement legislation. Within about ten years, all provinces except Newfoundland and Labrador, as well as the Yukon, had passed some form of conservation easement legislation. ${ }^{9}$ In the various pieces of legislation, the statutory interests enabled come under many names including conservation "easements," "covenants," "servitudes,” or "agreements." For convenience, this article refers to such interests as "conservation easements.”

easements) conditions placed on the servient tenement; the requirement for separate ownership and occupation of the dominant and servient tenements; and the fact that the common law interest could be defeated through a number of conditions over time, such as disuse of the benefit, changes in the local area of the servient tenement that are inconsistent with the restrictions or rights, or non-enforcement. In Alberta, the Land Titles Act, R.S.A. 2000, c. L-4, s. 68, allows the separately titled parcels to be owned by the same person.

8 The importance of meeting common law requirements is demonstrated by a 2004 Manitoba Court of Appeal decision: Willman v. Ducks Unlimited (Canada), 2004 MBCA 153, 245 D.L.R. (4th) 319. In the case, an agreement made by Ducks Unlimited Canada (DUC) and a landowner was set aside by the Court on the application of a successor landowner since the situation did not add up to a valid common law easement. The purpose of the agreement was to allow DUC to enter the land to develop and operate a waterfowl conservation project. Because there was no identifiable dominant tenement, the Court found that the agreement did not constitute an interest in land, and it was a mere licence enforceable only against the original parties.

Proceeding from the west, 1996 amendments to the British Columbia Land Title Act, R.S.B.C. 1996, c. 250, s. 219(3) authorize covenants for conservation purposes. The 1996 amendments to the Alberta Environmental Protection and Enhancement Act, R.S.A. 2000, c. E-12, ss. 22-24 [EPEA], authorize conservation easements. The 1996 Conservation Easements Act, S.S. 1996, c. C-27.01, enables conservation easements in Saskatchewan. Manitoba authorizes conservation agreements in The Conservation Agreements Act, C.C.S.M c. C173. Ontario’s Conservation Land Act, R.S.O. 1990, c. C.28, enables conservation covenants. The Quebec Natural Heritage Conservation Act, R.S.Q. c. C61.01, which replaced An Act Respecting Nature Reserves on Private Land, R.S.Q. c. R-26.2, authorizes conservation servitudes. New Brunswick's Conservation Easements Act, S.N.B. 1998, c. C-16.3, allows the creation of conservation easements. Nova Scotia's Conservation Easements Act, S.N.S. 2001, c. 28, which replaced the Conservation Easements Act, S.N.S. 1992, c. 2, authorizes conservation easements. Prince Edward Island's Natural Areas Protection Act, R.S.P.E.I. 1988, c. N-2, authorizes restrictive covenants to protect natural values. The covenants are tantamount to conservation easements in that the legislation states that such "restrictive covenants" may be positive or negative and do not require a dominant tenement (s. 5). The Environment Act, R.S.Y. 2002, c. 76, ss. 76-80, authorizes the granting of conservation easements in Yukon. 


\section{B. COMMON FEATURES OF CONSERVATION EASEMENTS}

Conservation easements, no matter what the jurisdiction, share many features. These include:

- The right of a landowner (the "grantor") to grant an interest in all or part of their property to specified qualified holders (the "grantee”) for purposes set out in the legislation.

- The express removal of all or many of the common law requirements and limitations noted above for similar partial interests in land, such as restrictive covenants and easements.

- $\quad$ Provisions stating that the interest runs with the land and accordingly binds future owners, and may be terminated only in specified circumstances.

- The anticipation or requirement that the interest be registered at the appropriate land titles or land registry office.

Each jurisdiction's legislation must be consulted to determine the precise rules governing the creation and life of such conservation interests. ${ }^{10}$ As these interests are statutory creations, non-compliance with statutory requirements could result in a court striking down the conservation easement.

\section{Conservation EASEMENT Legislation in Alberta}

In Alberta, conservation easements were made possible through a 1996 amendment to the EPEA. ${ }^{11}$ Under the legislation:

- A conservation easement may be granted by the registered owner of all or a part of land by way of agreement for one or more of the following purposes:

(a) the protection, conservation and enhancement of the environment, including, without limitation, the protection, conservation and enhancement of biological diversity;

(b) the protection, conservation and enhancement of natural scenic or esthetic values;

A source of general information on conservation easement-type interests in Canada is by Judy Atkins, Ann Hillyer \& Arlene Kwasniak, Conservation Easements, Covenants and Servitudes in Canada: A Legal Review (Ottawa: North American Wetlands Conservation Council (Canada), 2004). The text provides an overview of conservation easement legislation throughout Canada, and includes information on related topics, including drafting conservation easements, drafting conservation easement legislation, income and property tax implications, the American experience, and case law on conservation easements.

11 See Arlene Kwasniak, Conservation Easement Guide for Alberta (Edmonton: Environmental Law Centre, 1997) which contains detailed information about conservation easements. 
(c) providing for any or all of the following uses of the land that are consistent with purposes set out in clause (a) or (b):

(i) recreational use;

(ii) open space use;

(iii) environmental education use;

(iv) use for research and scientific studies of natural ecosystems. ${ }^{12}$

- A landowner may grant some of the rights to develop land to what the EPEA calls a "qualified organization." ${ }^{33}$ A "qualified organization" means the provincial government, a provincial government agency, a local authority including a municipality, or a body corporate that is a registered charity under the Income Tax Act, ${ }^{14}$ is constituted to hold conservation property interests, and meets other conditions set out in the legislation. ${ }^{15}$ In Alberta, there are a number of nongovernmental qualified organizations. ${ }^{16}$

- A conservation easement may exist for a term or be granted in perpetuity. ${ }^{17}$

- Conservation easements may be enforced by the grantee, a qualified organization appointed in writing by the grantor other than the grantee, or by both the grantee and the appointed qualified organization. ${ }^{18}$

- The "grantee may assign a conservation easement to another qualified organization." 19

- A properly constituted conservation easement that is registered at the appropriate Land Titles office binds not only the owner who originally granted it, but also future landowners. It runs with the land and is enforceable in accordance with the legislation and the terms of the agreement. ${ }^{20}$

- The legislation creating conservation easements explicitly removes many of the onerous conditions relating to restrictive covenants and easements, both being common law property interests that run with the land. ${ }^{21}$

Supra note 9, s. 22(2).

Ibid.

R.S.C. 1985, c. 1 (5th Supp.).

EPEA, supra note 9, s. 22(1)(e).

Organizations generally recognized in Alberta as being qualified organizations include the Nature Conservancy of Canada, the Alberta Fish and Game Association, DUC, the Alberta Sports Recreation Parks and Wildlife Foundation, the Alberta Conservation Association, Southern Alberta Land Trust Society, and others.

EPEA, supra note 9, s. 23(5).

Ibid., s. 22(3).

Ibid., s. 22(5).

Ibid., s. 24(1).

Ibid., s. 24(1) explicitly removes many common law conditions relating to restrictive covenants or easements. 
- A conservation easement may be amended or terminated by agreement of the grantor and grantee. As well, it may be modified or terminated by the Minister of Environment, but only in the public interest. ${ }^{22}$

- Conservation easements may be modified or terminated by court order on proof that the modification will be beneficial to the persons principally interested in its enforcement, or on proof that the easement conflicts with a land use bylaw or statutory plan under Part 17 of the Municipal Government Act. ${ }^{23}$

\section{Pluses ANd Pitfalls - Generally}

\section{A. Pluses}

A significant plus of conservation easements is that landowners may realize their conservation objectives and retain ownership of property without having to deal with common law rules. Related to this, land trust organizations may work to secure land to maintain critical wildlife habitat. Another plus is that conservation easements are useful for municipalities carrying out some of their land use objectives, as discussed in Part IV.

Another plus that may only be briefly described in this article, is that there can be income tax benefits for landowners who donate a conservation easement to a registered charity or to a level of government. A conservation easement is an interest in land, and in the usual case, transferring the interest through donation will be a disposition of capital property. ${ }^{24}$ If such a donation is certified under the federal Ecological Gifts Program, special rules apply. ${ }^{25}$ An "Ecological Gift" is a gift of land or an interest in land that the Minister of Environment certifies as important to the environmental heritage of Canada. The Minister also certifies the fair market value of the gift. ${ }^{26}$ As with regular gifts of capital property, the donee issues a tax receipt for the value of the gift and the individual grantor receives a tax credit. Tax credits are 16 percent of the first $\$ 200$ of the amount shown on the donation receipt and 29 percent

$22 \quad$ Ibid., s. 22(7).

23 R.S.A. 2000, c. M-26 [MGA]; EPEA, ibid., s. 24(3) states that ss. 48(4) and (6) of the Land Titles Act, supra note 7, apply. Courts have interpreted this Land Titles Act provision in respect of restrictive covenants, which are similar in relevant ways to conservation easements. The decisions state that the provision does not grant authority to modify or terminate a condition simply because the land use bylaw or statutory plan is more permissive than the covenant. In order for a court to have the right to modify or terminate, the covenant must directly conflict with the land use bylaw or statutory plan, for example, where complying with the covenant would lead to a violation of a bylaw. To illustrate, a court could not modify or terminate a covenant limiting building heights to two storeys where the bylaw would allow three storeys. However, it would have the right to modify or terminate a covenant restricting building height to more than two storeys where a bylaw restricts building height to two storeys: see Seifeddine v. Hudson Bay Traders (1980), 22 A.R. 111 (C.A.); Rockyview (Municipal District No. 44) v. Prince, [1996] A.J. No. 1347 (Q.B.) (QL); Crump v. Kernahan (1995), 173 A.R. 123 (Q.B.).

24 A disposition also could be of inventory, or an adventure in the nature of trade, and hence not a capital transaction. If this is so, the donation rules relating to capital property do not apply: see Environment Canada (EC), The Canadian Ecological Gifts Program Handbook (Gatineau: Environment Canada, 2005) at 6, online: EC <http://www.cws-scf.ec.gc.ca/egp-pde/6E9B56B5-A4c6-408F-863F-351E5A 4EE 83E/hand_e.pdf> [Ecological Gifts Handbook]. Ibid.

26 Income Tax Act, supra note 14, ss. 110.1(d), 118.1(1), s.v. “total ecological gifts.” 
of the balance. The calculated credit may then be used to reduce the amount of federal tax payable. Unused amounts may be carried forward for up to five years. ${ }^{27}$ Most provinces provide a similar provincial tax credit for charitable gifts.

There are benefits that pertain to Ecological Gifts that do not apply to regular gifts of capital property. First, the 75 percent of the donor's income limitation does not apply. Accordingly, there is no limit vis-à-vis the donor's income that applies when determining the maximum donation amount for a year. Second, for Ecological Gifts made before 2 May 2006, the taxable portion of any gain relating to the disposition of the land or interest in land is only 25 percent, and not 50 percent, as with regular gifts of capital property. ${ }^{28}$ Donations made on or after 2 May 2006 that have been certified under the Ecological Gifts Program will no longer be subject to capital gains. ${ }^{29}$ Finally, special "split-receipting" rules may apply for any gifts of capital property made after 20 December 2002. Split-receipting occurs when a grantor transfer of property to a registered charity or level of government is part gift and part consideration. With split-receipting, the donee may issue a tax receipt to a donor for the amount of the gift that is the difference between the total value of the gift and the value of any received consideration. ${ }^{30}$

\section{B. Pitfalls}

The greatest pitfalls to conservation easements are when they fail because they are:

(1) not properly constituted, and therefore potentially able to be overturned by a court;

(2) unenforceable because the grantee does not have power or funds to enforce;

(3) not flexible enough to accommodate changing situations; or

(4) not properly transparent enough to ensure that subsequent purchasers realize what they are buying.

Each of these is discussed in turn.

First, conservation easements are statutory constructions and therefore must comply with statutory requirements, or else a court might find them to be ultra vires, and hence render them to be nullities. An LL.M. student whom the author is supervising ${ }^{31}$ has identified

Ecological Gifts Handbook, supra note 24 at 4.

There are good resources on the federal tax consequences of gifts of conservation easements: see e.g. Judy Atkins \& Ann Hillyer, Land Conservation Transactions: Tax Implications of Gifts of Land and Interests in Land (Ottawa: North American Wetlands Conservation Council (Canada), 2005); M. Denhez, Giving Nature Its Due (Ottawa: North American Wetlands Conservation Council (Canada), 2003).

See Department of Finance Canada (DFC), The Budget Plan 2006: Focusing on Priorities (Ottawa: Her Majesty the Queen in Right of Canada, 2006), online: DFC < http://www.fin.gc.ca/budget06/bp/ bptoce.htm> at 231 .

Canada Revenue Agency (CRA), Income Tax Technical News, ITNEWS-26, "Proposed Guidelines on Split Receipting” (24 December 2002), online: CRA <http://www.cra-arc.gc.ca/E/pub/tp/itnews-26/> . Victoria Rowe, LL.M. candidate, Faculty of Law, University of Calgary. 
numerous issues with registered conservation easements. They mostly concern conservation easements that were not constituted for permitted purposes. For example, there is nothing in the Alberta conservation easement legislation that enables a conservation easement to be constituted to protect agricultural operations per se. ${ }^{32}$ The legislation, as set out above, enables the protection of biodiversity, or natural scenic or aesthetic values. Accordingly, a conservation easement that does not fit into one of these categories could be overturned by a court. An example would be a conservation easement that is designed to protect hunting land, cultivated agricultural land, or ranching operations per se (in contrast to, for example, a prairie grassland ecosystem). Drafters of conservation easements must be vigilant to ensure that their agreements fit within permitted purposes.

Second, although the author is not aware of published evidence of problems in Canada, there is published evidence from the U.S. where conservation easements are not enforced because of lack of funds or person-power. ${ }^{33}$ This material cites examples where a land trust or other grantee, although well meaning at the time of the acquisition, must "let" infractions go by because of lack of monitoring power, funds, and staff. The lesson is that an organization should not be the grantee of a conservation easement unless there is assurance that it has the funds to monitor and enforce.

Third, American and Canadian speakers on conservation easements repeatedly express problems owing to the lack of flexibility. If conservation easement terms are too inflexible, they will likely be violated. The grantee may be compelled to allow minor violations, and then allow more serious violations, since a pattern of non-enforcement has been set. As a result, mandatory terms of a conservation easement are interpreted to be discretionary. ${ }^{34}$ Tools such as mediation to deal with alleged infractions will help, but in the end it is likely best to ensure that the grantor requirements are not too strict, while, of course, ensuring that the terms are strict enough to constitute covenants to protect environmental values, as required by legislation — a delicate balance indeed.

Fourth, American cases make it clear that the usual party to challenge a conservation easement is a subsequent owner of the burdened property..$^{35}$ To address this, purchasers must be made aware of the seriousness of the restrictions on property before they purchase. If at all possible, the grantee should get acknowledgment agreements from subsequent purchasers

32 Whether a conservation easement may be used in a province to protect agricultural land per se depends on the legislation of the province. For example, as noted in Part IV of this article, s. 3(2)(d) of the Ontario Conservation Land Act, supra note 9, authorizes the use of a conservation easement to protect "land for agricultural purposes."

$33 \quad$ Katie Paris prepared an interesting study for the Nature Conservancy of Canada on this and related subjects: "Land Trusts: Measuring the Effectiveness of Conservation Easement Programs" (Ottawa: Nature Conservancy of Canada, 2004).

$34 \quad$ These problems are discussed in "Ensuring the Promise of Conservation Easements: Report on the Use and Management of Conservation Easements by San Francisco Bay Area Organizations” (14 May 1999), online: Bay Area Open Space Council <http://www.openspacecouncil.org/projects/ easements/baosc_easement_1999.05.14_ensuring_the_promise.pdf $>$.

35 See Paris, supra note 33 at 8 where she states that "[c] [challenges to ensuring that conservation easements will last in perpetuity would commonly stem from the following conditions, which this paper will address in turn: Subsequent landowners violate easements, attempt to challenge validity of easements, or attempt to weaken easements by modifying terms.” 
to better ensure that they are aware of the nature of restrictions and requirements. Conservation easement agreements should include terms that require the grantor to give notice to the grantee of any potential transfer of the property subject to the conservation easement.

\section{Pluses and Pitfalls in Municipal Use OF CONSERVATION EASEMENTS}

\section{A. Pluses}

Currently, the laws of nine of the ten jurisdictions in Canada with conservation easement legislation specifically allow municipalities to hold conservation easements. ${ }^{36}$ If Alberta serves as an example, municipalities can use conservation easements in two discrete manners. First, a municipality may use a conservation easement in a proactive manner outside of municipal land use planning, subdivision, and development processes. Second, a municipality may use a conservation easement in a reactive manner within these processes. As this part of the article establishes, in both of these cases, municipalities benefit in that conservation easements provide a tool for them to realize their municipal and land use planning objectives where other tools are not sufficient.

\section{Pluses in Proactive Use}

In using conservation easements in a proactive manner, a municipality will either approach a landowner to acquire a conservation easement interest, or, will become a holder at the request of a landowner. Provided that authorizing legislation enables municipalities to acquire interests in land for municipal purposes, there should be no jurisdictional issues regarding whether a municipality has authority to hold a conservation easement provided the acquisition was to serve some municipal end.

\section{Pluses in Reactive Use}

A municipality uses conservation easements within land use planning, subdivision, and development processes for added flexibility or to assist the municipality in carrying out environmental policies when other tools fall short. In some cases, a municipality may use conservation easements to realize policy objectives when other legislative tools are not appropriate to realize this end.

Consider Alberta as an example. In Alberta, land use planning, subdivision, and development processes are authorized under Part 17 of the $M G A \cdot{ }^{37}$ In the context of a subdivision application, in some circumstances, the municipal subdivision authority may

\footnotetext{
36 The Quebec legislation does not authorize municipalities to hold conservation servitudes: see National Heritage Conservation Act, supra note 9. 
require the applicant owner to dedicate land as a municipal or environmental reserve. ${ }^{38}$ Here are pertinent facts about reserves in Alberta:

- $\quad$ Land may be taken as municipal reserve only to be used for the following purposes: a public park, a public recreation area, a school, or to separate areas of land that are used for different purposes. ${ }^{39}$

- $\quad$ Land may be taken as environmental reserve only if it consists of a swamp or a gully; land that is subject to flooding or in the opinion of the subdivision authority is unstable; a strip of land not less than six metres in width abutting the bed and shore of any lake, river, stream, or other body of water to prevent water pollution or to provide public access. ${ }^{40}$ It is clear from the characterization of "environmental reserve" that it is intended to be taken only where land is essentially unable to be developed.

- Where the municipality and the landowner agree, environmental reserve may be taken as environmental reserve easement. The main difference between environmental reserve and environmental reserve easement is that with the latter, title to the reserve land remains in the name of the landowner. An environmental reserve easement may be registered on title by caveat in favour of the municipality. Land subject to an environmental reserve easement must remain in a natural state. ${ }^{41}$

- The legislation limits dedications of municipal reserve to 10 percent of the area sought to be subdivided less the area taken as environmental reserve, or such lesser amount set forth in the municipal development plan. ${ }^{42}$ The 10 percent may not cover the area the municipality wishes to protect, and the municipality may need some or even all of the 10 percent for schools, playgrounds, or like purposes. Although the $M G A$ does not limit the amount that a municipality may require as environmental reserve, it may not claim reserve unless the land meets the definition of environmental reserve. ${ }^{43}$

Assume the land that is the subject of a subdivision application contains valuable wildlife habitat that the municipality would like to remain undeveloped in accordance with the municipality's wildlife habitat protection policy. Taking land as municipal or environmental reserve to achieve the municipal wildlife habitat protection policy objectives may be appropriate where those objectives are met by the reserve land being used for one or more

See ibid., s. 663: no dedication of environmental or municipal reserve may be required where:

- the subdivision creates only one lot out of a quarter section,

- the subdivision creates lots of 16 hectares or more which solely will be used for agricultural purposes,

- the land to be subdivided is 0.8 hectares or less, or,

- land or money in lieu of land was provided in respect of an earlier subdivision creating the parcel in respect of which subdivision now is sought.

Ibid., s. 665(1).

Ibid., s. 664(1).

Ibid., s. 664(2)-(3).

Ibid., s. 666(2).

See ibid., s. 664 . 
of the authorized purposes for the reserves. The municipality might be able to extract some protection under a required municipal reserve (use as a park) but this might not be sufficient. If the land does not qualify as an environmental reserve (for example, because it is not a swamp, a gully, subject to flooding, or adjacent to a water body) then to save the habitat, the municipality must either deny the subdivision application (if it has valid planning reasons to do so), expropriate the land, negotiate a purchase, or attempt to secure the co-operation of the developer not to destroy the habitat. If the municipality takes the last course of action, it could try to negotiate a conservation easement to protect the habitat that cannot be protected through dedications. Perhaps the municipality could offer concessions in return, such as higher densities or reduced road dedications, levies, or servicing costs. In this way, the municipality may overcome limitations of its land use planning and development authority in order to realize municipal objectives.

Entering into a conservation easement in the land use planning, subdivision, and development process can benefit both the municipality and the developer. With respect to the municipality, the municipality can limit or prohibit development in sensitive habitat areas while not having to acquire the land through purchase, expropriation, or through potentially unlawful reserve extractions. Even if land is otherwise qualified for environmental reserve status, a municipality might consider negotiating a conservation easement instead of taking reserves. For example, under the $M G A$, when a municipality takes an environmental reserve, title to the land usually transfers to the municipality and the land must be left in its natural state or be used as a park. ${ }^{44}$ If a conservation easement were negotiated instead, the municipality would not be left owning an isolated piece of land and there can be more flexibility with respect to use of land ${ }^{45}$ With respect to the landowner, the landowner could benefit by granting a conservation easement instead of giving an environmental reserve. With environmental reserves the landowner loses ownership of the land, but with a conservation easement, the landowner retains ownership of the land. With a conservation easement, the landowner and the municipality may negotiate what uses may be made of the land and whether there should be any public access. With environmental reserves, normally the municipality allows public access. Although the MGA allows an environmental reserve to be taken as an environmental reserve easement when the municipality and the landowner agree, environmental reserve easements are not as flexible as conservation easements. Although with environmental reserve easement title remains with the landowner, the MGA requires that it be a term of the easement that the land be left in a natural state as if owned by the municipality. ${ }^{46}$ Other than this, it is not clear from the $M G A$ whether an environmental reserve easement can contain any other requirement, or allow any use by the landowner.

\footnotetext{
$44 \quad$ Ibid., s. 671.

45 A conservation easement may allow uses provided that they are consistent with the legislated purposes of the conservation easement.

46 MGA, supra note 23, s. 664(3)(b).
} 


\section{B. Pitfalls}

\section{ESTABLISHING JURISDICTION AND A JURISDICTIONAL ISSUE}

Although both the landowner and the municipality might benefit by negotiating a conservation easement within the land use planning, subdivision, and development process, the question still remains: may municipalities enter into conservation easements as a part of these processes when the statute authorizing them does not mention conservation easements, though conservation easements are authorized by other legislation? Legislation throughout Canada expressly authorizes municipalities to enter into conservation easements. But does it follow from this that municipalities may use conservation easements in land use planning, subdivision, and development processes? No province in Canada that the author is aware of has legislation that expressly authorizes municipalities to use conservation easements in these processes. For example, in Alberta the EPEA expressly authorizes municipalities to be granted conservation easements, while the MGA expressly authorizes municipalities to carry out certain land use planning, subdivision, and development processes. In Ontario, the Conservation Land $A c t^{47}$ authorizes municipalities to be granted conservation easements, while the Planning Act ${ }^{48}$ authorizes land use related functions. Thus the jurisdictional issue is whether a municipality may negotiate conservation easements, which are authorized under one statute, in carrying out land use planning, subdivision, and development processes, in particular subdivision processes, under other legislation (or, in some provinces, a discrete part of the same statute).

The particular jurisdictional issue is not hypothetical. It has been raised in both Alberta and Ontario. ${ }^{49}$ The following two sections discuss these cases and present legal arguments as to why conservation easements, where a landowner is willing, may be used in exercising authorities under planning and development legislation.

\section{ALBERTA DECISIONS ON A MUNICIPALITY's USE OF CONSERVATIONEASEMENTS IN LAND SUBDIVISION CONTEXTS}

This matter has come before the Alberta Municipal Government Board (MGB), one of the boards that hear subdivision and development appeals in the province. For example, in Marler v. Strathcona (County of), ${ }^{50}$ a landowner objected to the County's suggestion that she enter into a conservation easement in connection with a proposed subdivision. Strathcona County preferred a conservation easement over environmental reserve because a conservation is more flexible and can protect areas beyond those that qualify as environmental reserve. The appellant argued that conservation easements may not be used in connection with MGA Part 17 activities. She contended that when conducting land use planning, subdivision, and development processes, municipalities are limited to Part 17 powers. So, a municipality may require a dedication of environmental or municipal reserve in the context of a subdivision application, but it may not step

$47 \quad$ Supra note 9.

$48 \quad$ R.S.O. 1990 , c. P.13.

49 A Lexis-Nexis Canada tribunal search of the term “conservation easement” conducted on 7 May 2008 rendered only Ontario and Alberta board decisions.

50 (27 July 2001), MGB 102/01, online: MGB <http://www.municipalaffairs.gov.ab.ca/cfml/boardorders/ pdf/M102-01.pdf> [Marler]. 
out of Part 17 of the MGA and over to the EPEA and carry out EPEA powers to negotiate conservation easements in the context of the subdivisions process. A similar position was put forth in Massey v. Strathcona (County of).$^{51}$ In this proceeding the applicants sought a zoning bylaw change and subdivision approval. The current zoning allowed no parcels under 160 acres (to protect agricultural land) and they wanted to subdivide their 36.6-acre parcel into two parcels, one approximately 20 acres and one 16.6 acres in size. The land, located near Half Moon and Cooking Lakes, was subject to the County's Lakeland Management Plan which strove to protect wildlife habitat patterns from development. Some of the habitat constituted environmental reserve, but some did not. The County wanted the applicants to enter into a conservation easement so that all critical wildlife habitat on the property would be protected from development. The applicants, however, were appalled that the County suggested that environmental reserve be taken in the form of conservation easement. ${ }^{52}$

In both decisions the MGB did not accept the applicant's contention that a municipality may not use conservation easements within the context of exercising Part 17 powers. However, in both decisions the MGB strongly stated that a municipality may not force a conservation easement on a landowner. Conservation easements are voluntary by nature and may only be used where there is an obliging landowner. It is interesting that in subsequent cases the Board takes for granted that conservation easements may be used in the context of a subdivision application, provided that the landowner is willing. ${ }^{53}$

However, in neither of the above noted decisions did the Board offer legal arguments to conclude that a municipality may, as a matter of law, use legislative authority outside of Part 17 of the MGA within the context of a Part 17 subdivision application, and more particularly, use conservation easements within this process.

\section{ONTARIO DECISIONS}

The 1998 Ontario Municipal Board (OMB) decision Orrico v. Markham (Town of) Committee of Adjustment ${ }^{54}$ concerned both a proposed conservation easement to protect a wetland complex and a proposed agricultural conservation easement to protect farmland as a condition for the approval of conveyance of three parcels of land. The Ontario conservation easement legislation, by contrast to Alberta's legislation, specifically enables a conservation

(8 May 2003), MGB 064/03, online: MGB <http://www.municipalaffairs.gov.ab.ca/cfml/boardorders/ pdf/M064-03.pdf> [Massey]; see also Re Stewart (29 August 2001), MGB 121/01, online: MGB $<$ http://www.municipalaffairs.gov.ab.ca/cfml/boardorders/pdf/M121-01.pdf>.

Massey, ibid. at 14.

See e.g. Re 1205315 Alberta Ltd. (19 February 2008), MGB 023/08, online: MGB <http://www. municipalaffairs.gov.ab.ca/cfml/boardorders/pdf/M023-08.pdf >; Charlton v. Sturgeon (County of) (2 March 2007), MGB 021/07, online: MGB <http://www.municipalaffairs.gov.ab.ca/cfml/boardorders/ pdf/M021-07.pdf>; Thomas v. Strathona (County of) (29 August 2007), MGB 113/07, online: MGB <http://www.municipalaffairs.gov.ab.ca/cfml/boardorders/ pdf/M113-07.pdf>; Kanke v. Strathcona (County of) (28 September 2005), MGB 098/05, online: MGB <http://www.municipalaffairs.gov.ab.ca/ cfml/boardorders/pdf/M098-05; LaBine v. Strathcona (County of) (30 January 2003), MGB 16/03, online: MGB <http://www.municipalaffairs.gov.ab.ca/cfml/boardorders/pdf/M016-03.pdf >; Walker v. Strathcona (County of) (22 April 2003), MGB 055/03, online: MGB <http://www.municipal affairs.gov.ab.ca/cfml/boardorders/pdf/M055-03.pdf>. 
easement to be granted to protect agricultural land. ${ }^{55}$ The municipality and the landowner apparently had already agreed to the conservation easement to protect the wetlands. The agricultural easement was proposed not by the parties to the conveyance, but rather by interveners. The lands in question were designated for agricultural preserve in the Regional Official Plan, the Town's Official Plan, and were zoned for agricultural uses. Nevertheless some interveners in the proceeding believed that their preservation for agricultural purposes would only be secured by the Board imposing an agricultural conservation easement as a condition of approval. ${ }^{56}$ Although the Board readily agreed to the "imposition" ${ }^{\text {"57 }}$ of a conservation easement, it did not agree to the imposition of an agricultural easement. ${ }^{58}$ A planner for the Town of Markham argued that "such an easement usurps the substantial and public process set out in the Planning Act, and that the tools provided in the Planning Act were adequate and democratic, subjecting any major land use change to a comprehensive and public analysis."59 The Board agreed with the Town's representative. It also noted that where an easement may be "discharged by agreement of the parties only, which also serves to exclude the public."60 It concluded this issue by stating that "[a]gricultural easements are a new idea, and until the implications and nuances of such an instrument are thoroughly canvassed, and its legality and usefulness proven, this Board member is not prepared to impose such a requirement as a condition of planning approval." 61

In the author's opinion, the Board was correct in not imposing an agricultural easement. Agricultural conservation easements, like any conservation easements, are voluntary instruments and should not be imposed by government officials or tribunals, unless prevailing legislation enables this. In this case, the Town's representative expressed that the Town was not in favour of an agricultural conservation easement and so it should not be a surprise that the Board did not independently advocate for one. Nevertheless, the Board's comments regarding the lack of public process and public accountability with respect to conservation easements warrant a response.

It is true that conservation easements, whether to protect agricultural uses or to limit development to protect environmental features, do not require a public process and they could limit land uses more restrictively than the applicable zoning rules. But is this a reason why they should not be used by a municipality when exercising land use planning and development authority? The author cannot see why. In the first place, there might well be some kind of public process involved when a municipality enters into a conservation easement. For example, if the decision to be the grantee of a conservation easement is made by resolution, then the resolution likely would be made at a council meeting, which would normally be public. Second, given that such a conservation easement would be entered into in the context of a subdivision or development, the agreement would likely be aired in a public context. Third, assuming that a

Conservation Land Act, supra note 9, s. 3(2)(d), authorizes the use of a conservation easement to protect "land for agricultural purposes."

Orrico, supra note 54 at para. 10.

The word "imposition" is in scare quotes since technically a conservation easement may not be imposed on a party since conservation easements are voluntary. It is suggested that the Board meant that the Board would consent to the conveyance if the parties entered into a conservation easement.

Orrico, supra note 54 at para. 20.

Ibid. at para. 16.

Ibid. at para. 21.

Ibid. 
municipality has the legislative authority to enter into a conservation easement within a land use planning and development context and a landowner and the municipality wished to do so (discussed in the next section), it would be odd, and likely appealable, if a tribunal overturned this aspect of municipal authority's decision on the grounds that a public process was not involved.

It is interesting that in Ontario, just as in Alberta, over time, conservation easements became "old hat" to the Municipal Board and their presence in municipal appeals is accepted without comment. $^{62}$

\section{THE JURISDICTIONAL ISSUE}

\section{INTRODUCTION}

Neither the Ontario nor the Alberta tribunals squarely addressed the jurisdictional issue of whether a municipality has the jurisdiction to use conservation easements when carrying out its land use and development authorities. Nevertheless, the issue could come before a court. If it did, what arguments could be presented that the legislation either limits or does not limit municipalities to their specific subdivision and development powers when carrying out land use planning and development functions?

This section sets out a statutory interpretation analysis of Alberta legislation and concludes that an Alberta municipality may use conservation easements while carrying out land use planning and development functions. Although this article does not contain a comparable analysis for Ontario or other provinces, the Alberta analysis provides a framework for how a comparable argument might proceed.

On the basis of the analysis in this section, the author concludes that, given the absence of statutory language to the contrary, an Alberta subdivision authority may cross over the EPEA and invoke EPEA powers to be granted conservation easements when carrying out MGA subdivision processes.

\section{CLARIFYING THE JURISDICTIONAL ISSUE}

Section 5 of the MGA states that a municipality has the power to carry out authorities and functions given by the $M G A$ as well as other legislation. So municipalities clearly have the power to enter into conservation easements since the EPEA authorizes them to hold such easements. The jurisdictional issue is not whether Part 17 impliedly authorizes the use of conservation easements in land use planning, subdivision, and development processes. Rather, the issue is, given the existence of the express power under the EPEA that municipalities may hold

See e.g. Sotirakos v. Toronto (City of) (12 July 2007), OMB 1969, online: OMB <http://www.omb.gov. on.ca/english/eDecisions/eDicisions.html>; Thornwood Developments Group v. Oakwille (Town of) (22 June 2006), OMB 1794, online: OMB < http://www.omb.gov.on.ca/english/eDecisions/eDecisions. html>; Aon Inc. v. Port Hope (Municipality of) (8 December 2004), OMB 1900, online: OMB <http://www.omb.gov.on.ca/english/eDecisions/eDecisions.html>; Village Securities Ltd. v. Toronto (City of) (21 June 2001), OMB 0999, online: OMB <http://www.omb.gov.on.ca/english/eDecisions/ eDecisions.html>. 
conservation easements and the MGA's affirmation that municipalities have powers under the MGA and other legislation, is there anything in Part 17 that would preclude Alberta municipalities from using conservation easement in the land use planning, subdivision, and development processes, particularly subdivision.

\section{PRESUMPTION OF COHERENCE}

The presumption of coherence presents a stumbling block to those who would contend that conservation easements cannot be used by a municipality in carrying out Part 17 land use planning, subdivision, and development processes. The presumption is that the provisions of legislation - in this case the conservation easement provisions of the EPEA and Part 17 of the $M G A$ - are meant to work together as part of a functioning whole. ${ }^{63}$ As long as the provisions in the two pieces of legislation can apply to the same facts, it is presumed that the legislature meant them to apply. ${ }^{64}$ So, as long as a municipality can enter into a conservation easement in respect of land under the EPEA and can carry out land use planning, subdivision, and development processes in respect of that land under the $M G A$, the presumption is that the legislature meant for either or both of the EPEA and MGA authorities to apply.

\section{EXHAUSTIVE CODE}

The presumption of coherence is rebutted by evidence that one set of legislative provisions was intended to be an exhaustive declaration of the applicable law. ${ }^{65}$ Since there is nothing in the EPEA conservation easement provisions that appears relevant to the issue of exhaustive code, the issue is whether Part 17 of the MGA, in particular the subdivision provisions, sets out an exhaustive code regarding what municipalities may do in respect of a subdivision. If the subdivision provisions are an exhaustive code, then presumably, a municipality may require only the reserves set out in Part 17 in a subdivision process and may not negotiate EPEA authorized conservation easements.

As with all questions of statutory interpretation, determining whether statutory provisions are meant to be an exhaustive code boils down to determining whether the legislature intended the provisions to be an exhaustive code. For the issue at hand, in determining legislative intent, the first question is whether the language used in the MGA subdivision statutory provisions expressly or implicitly limits the statutory authority’s powers to those given in Part 17.

The relevant reserve sections of the MGA, ss. 661-66, state that the owner must provide roads, public utilities, municipal, or environmental reserves without compensation, as required by the subdivision authority; set out limits for road and utility reserves, and municipal reserves; address when a reserve may be required; and define what constitutes environmental reserve. Nothing in these sections expressly prohibits the authority from negotiating a voluntary EPEA conservation easement instead of the authority requiring a mandatory dedication. Did the legislature implicitly intend such limitation? 
According to Ruth Sullivan and Elmer Driedger, courts sometimes invoke the maxim expressio unius est exclusio alterius in determining whether provisions are exhaustive. ${ }^{66}$ However, recourse to the maxim does not help address the issue at hand. The noted provisions might well be exhaustive regarding when a subdivision authority extracts mandatory dedications without compensation. However, the issue at hand is not whether a subdivision authority may extract dedications in addition to those set out in the MGA subdivision provisions. The issue is whether the municipality may use its powers under the EPEA to restrict uses of land pursuant to a conservation easement instead of taking reserve. Accordingly, the maxim is not useful in addressing the jurisdictional issue.

Another way to support a claim of exhaustive code is by recourse to evidence of legislative intent through considering legislative evolution and legislative history. ${ }^{67}$ It is hard to see how such recourse could be of any use to someone attempting to establish that the subdivision provisions of the $M G A$ are an exhaustive code such that conservation easements may not be used in the subdivision process. The MGA was largely revamped in 1995. Legislative history clearly indicates the intention to enlarge municipal authorities generally, and not to limit or narrow them. The words used to introduce the bill in the Legislative Assembly were, "[t]his legislation reflects the government's commitment to put more decision-making in the hands of local authorities. It will provide municipalities with greater flexibility to respond to changing conditions now and in the future." $" 68$

Another way to support a claim of exhaustive code is by recourse to case law interpreting comparable provisions. Again, this manner of support does not seem available. There is case law that would support a claim that some provisions in the land use planning, subdivision, and development part of the $M G A$ are exhaustive, or something akin to exhaustive, but they are not relevant to the issue at hand. For example, the Alberta Court of Queen's Bench in Urban Development Institute v. Rocky View (Municipal District No. 44) ${ }^{69}$ determined that a municipality could not levy fees against developers of new subdivisions in the municipality to generally maintain and improve roads in the general area of the subdivision where the authorizing legislation only authorized the municipality to require the developer to pay to construct roads that give access to a subdivision. ${ }^{70}$ This case has nothing to do with whether a municipality can use other legislation than that found in Part 17. This issue was not raised in, nor did it have any relevance to, the case.

There is relevant case authority that a municipality is not limited to Part 17 specifically authorized powers when carrying out land use planning, subdivision, and development

$66 \quad$ Ibid. at 266.

$67 \quad$ Ibid., referring to Perron-Malenfant v. Malenfant (Trustee of), [1999] 3 S.C.R. 375.

68 Bill 31 incorporated, modified, and consolidated municipal land use planning, subdivision, and development provisions formerly in the Planning Act, R.S.A. 1980, c. P-9 into the MGA, supra note 23, giving considerably more power to municipalities regarding subdivisions than was possible under the Planning Act. For example, subdivision applications under the MGA are decided locally instead of by a regional authority: see Alberta, Legislative Assembly, Hansard (2 May 1994) at 1576 (Judy Gordon).

692002 ABQB 651, 321 A.R. 253.

$70 \quad$ Ibid. at paras. 64-65, citing MGA, supra note 23, s. 650(1)(a). 
processes. In 698114 Alberta Ltd. v. Banff (Town of), ${ }^{71}$ the Alberta Court of Appeal found that a municipal bylaw creating a lottery system for limiting commercial growth was valid notwithstanding that the MGA did not specifically authorize such allotment process. The Court agreed with the chamber judge's conclusion that

\begin{abstract}
The allotment system provided under Bylaw 31-3 is quite logically the regulation and control of the development of the land within the Town pursuant to a new philosophy of commercial development control. Section 640(1) is distinct from s. 640(2) and the s. 640(2) requirements relating to development permits. Bylaw 31-3 still meets the requirements under s. $640(2)$ : it divides the municipality into districts, prescribes the permitted or discretionary uses, and establishes the means by which decisions will be made regarding development permits. However, in addition to this, the Town has decided to further regulate land development by instituting a random allotment system. While this is not specifically authorized by the Municipal Government Act, the broad powers of regulation and control outlined in s. 640(1) provide the Town with legal authority to create such a system. ${ }^{72}$
\end{abstract}

The legal finding in 698114 Alberta is strengthened by the fairly recent decision of the Supreme Court of Canada in United Taxi Drivers' Fellowship of Southern Alberta v. Calgary (City of). ${ }^{73}$ In that case, the Alberta Court of Appeal strictly construed the MGA's bylaw making authority and found that the Act did not give Calgary the right to limit the number of taxi plates that may be issued, and thereby limit the number of taxis in the city. The Supreme Court allowed the municipality's appeal. The Court confirmed a setting aside of the “'benevolent' and 'strict' construction dichotomy" prevalent in earlier cases in favour of a "broad and purposive approach."74 In using this approach, the Court found that the municipality had the power to limit the issuance of taxi plates, either by its power to regulate (MGA, s. 8(a)) or its power to provide for a system of licenses (MGA, s. 8(c)).

On the basis of the above arguments, the author concludes that there is little, if any, reasonable chance that a court would find that the subdivision provisions in Part 17 constitute an exhaustive declaration of the law in such a way that would prevent a subdivision authority from negotiating a conservation easement with an applicant in the course of the subdivision process.

2000 ABCA 237, 266 A.R. 70 at paras. 4-5 [698114 Alberta]. Banff is located within a National Park and is a creature of both federal and provincial legislation, namely the National Parks Act, R.S.C. 1980, c. N-14 and the Parks Town Act, S.A. 1989, c. P-1.5. The Federal and Alberta governments incorporated the Town effective 1 January 1990 pursuant to an incorporation agreement. Under the agreement, all planning laws of Alberta (in the MGA) apply to Banff, subject to the agreement. Ibid. at para. 27. MGA, supra note 23, s. 640(1) states that "[a] land use bylaw may prohibit or regulate and control the use and development of land and buildings in a municipality." 2004 SCC 19, [2004] 1 S.C.R. 485.

Ibid. at para. 6 . 


\section{CONSIDERATIONS FOR MUNICIPALITIES CONTEMPLATING USING \\ CONSERVATION EASEMENTS IN LAND USE PlaNNING, SubDivision, AND DEVELOPMENT PROCESSES}

\section{A. INTRODUCTION}

This part briefly identifies and addresses a number of issues that municipalities should consider if they contemplate using conservation easements in land use planning, subdivision, development, or other municipal processes. The issues discussed are not exhaustive of matters that should be considered by municipalities, but they raise key issues. ${ }^{75}$

\section{B. REFLECTION IN LAND USE Plans AND BylaWS}

In Alberta, municipal policies to protect important environmental features typically would be set out in municipal plans. More regulatory aspects of municipal land use planning and development processes are set out in land use bylaws. Comparable regimes apply to other provinces. If municipalities intend to use conservation easements in land use planning, subdivision, and development processes, subject to any limitations set by authorizing legislation, it is advisable that this intention be set out in municipal policies and in bylaws. In its policy and regulatory documents, in describing how a municipality intends to use conservation easements, the municipality should establish how the use relates to the municipality carrying out its municipal purposes as set out in authorizing municipal legislation. If conservation easements are contemplated in plans and bylaws as a method (among others) to achieve municipal policy objectives, then there is less room for complaint or legal challenge when the municipality negotiates their use. ${ }^{76}$

\section{CONSERVATION EASEMENTS AND SUBDIVISION REQUIREMENTS}

In the author's experience, it appears to be generally held by practitioners that placing a conservation easement on property does not require formal subdivision of the parcel, even where

75 For a summary of how conservation easements have been used in the municipal context in a U.S. urban development context, see G.S. Kleppel, "Urbanization and Environmental Quality: Implications of Alternative Development Scenarios” (2002) 8 Alb. L. Envtl. Outlook 37.

76 For an example of how a municipal action may be challenged for not falling within a municipal purpose, see Shell Canada Products Ltd. v. Vancouver (City of), [1994] 1 S.C.R. 231. The case considered whether the Vancouver City Council acted within municipal authority as set out in the Vancouver Charter, S.B.C. 1953, c. 55, in passing resolutions based on concerns related to apartheid. The resolutions provided that the City would not conduct business with Shell Canada Products Ltd. until Royal Dutch Petroleum Company of the Netherlands and the Shell Transport and Trading Company, p.l.c. , of the United Kingdom completely withdrew from South Africa. In this close, 5-4 decision, the majority of the Supreme Court found that the City did not have jurisdiction to pass the resolutions since they did not relate to a municipal purpose. The dissent found that the resolutions did fall within municipal authority. The key legislated municipal purpose considered by the Court was that Council "may provide for the good rule and government of the city" (Vancouver Charter, s. 189). The majority found that while council may have regard for matters beyond its boundaries in exercising its powers, any municipal action must benefit the citizens of the City. The majority did not find a connection between the boycott and the benefit to citizens. One may speculate how the decision would have gone if the municipality, in its policies, provided for the use of such boycotts and reasonably set forth how their use benefits citizens. 
conservation easement legislation in Canada is not explicit on this matter. The author assumes this is held to be the case because normally, the placing of similar instruments, such as common law restrictive covenants and easements, do not give rise to a subdivision approval requirement. In Alberta and perhaps in other provinces, the belief is bolstered by legislative authority that suggests that conservation easements do not require subdivision approval. In Alberta, the land use planning, subdivision, and development provisions of the MGA state that the Registrar of Land Titles "may not accept for registration an instrument that has the effect or may have the effect of subdividing a parcel of land unless the subdivision has been approved by a subdivision authority." $" 77$ Under this provision, a conservation easement that might have the effect of subdividing a parcel would need subdivision approval. However the conservation easement provisions of the EPEA state that when a conservation easement is presented to the Registrar of Land Titles, the "Registrar shall endorse a memorandum of the agreement on the certificate of title to the land that is the subject of the agreement."78 This provision appears to override the subdivision requirements of the $M G A$.

Nevertheless, it is not beyond imagination that the Registrar of Land Titles, if faced with a conservation easement that gave substantial control to the grantee, might refuse to register it on the ground that it subdivides the property and ask a court for direction in the face of apparently conflicting legislation. ${ }^{79}$ The author is of the view that the direct requirement to register in the EPEA in all likelihood overrides the noted MGA provisions, but it is not possible to predict how any particular judge might see the situation.

Accordingly, municipalities should consider whether a conservation easement has the effect of subdividing property and if it does, ensure that any legislative requirements are met. In Alberta, even disregarding the EPEA's directive to register conservation easements, it is highly unlikely that the Registrar would consider not registering a conservation easement on the ground that it would likely subdivide the parcel. This is because "as a matter of practice, registrars of title treat an instrument that creates an interest in part of a parcel as a subdivision only where the granting instrument confers unto the grantee an exclusive right of use and enjoyment." ${ }^{\text {"To }}$ The author is not aware of any conservation easements that confer such control. Nevertheless, legal due diligence requires consideration of the subdivision issue.

\section{MODIFICATION AND TERMINATION OF CONSERVATION EASEMENTS}

Land use planning, subdivision, and development legislation usually set out how, if ever, dedications or other land use restrictions may be modified or terminated. For example, the $M G A$ gives municipalities the right to alter the use of environmental reserve following a publicly advertised meeting. ${ }^{81}$ The British Columbia Local Government Act contains provisions enabling municipalities, subject to certain process requirements, to exchange parkland required in the context of a subdivision for other suitable land, or, to sell part of the parkland and deposit the

MGA, supra note 23, s. 652(1).

EPEA, supra note 9, s. 23(3).

Land Titles Act, supra note 7, s. 185, enables the Registrar to refer questions to a judge when the Registrar is uncertain how to proceed.

80 Frederick A. Laux, Planning Law and Practice in Alberta, 3d ed., looseleaf (Edmonton: Juriliber, 2002) at para. 11.4(6).

MGA, supra note 23, s. 676(1). 
proceeds in a parkland acquisition fund. In either case, the land exchanged or sold is freed from the parkland designation. ${ }^{82}$ Other provinces' legislation would reveal more examples.

Legislative provisions regarding modification and termination of conservation easements typically fall under legislation other than municipal land use planning, subdivision, and development provisions. These provisions may differ significantly from the modification or termination provisions relating to standard dedications or other land use restrictions given in the context of a subdivision. For example, in Alberta, the EPEA states that a conservation easement may be amended or terminated by written agreement of the grantor and grantee. It may be modified or terminated by the Minister of Environment in the public interest. ${ }^{83}$ The British Columbia Land Title Act states that a conservation covenant may be modified by written agreement between the grantee and grantor and that they may be unilaterally cancelled by the covenant holder. ${ }^{84}$ As well, under the Property Law Act, "a person interested in land" may, for the reasons set out in the legislation, apply to the court for an order to modify or cancel a covenant under s. 219 of the Land Title Act. ${ }^{85}$

Thus, the fate of conservation easements may be different from the fate of standard extractions and may be out of the control of the municipality. Municipalities should consider the ramifications of this when they contemplate using conservation easements instead of authorities specifically authorized in subdivision provisions.

\section{E. HOLDER OF A CONSERVATION EASEMENT}

A conservation easement may be granted to or held by whom or whatever is determined by the authorizing legislation. For example, as mentioned earlier, in Alberta, a conservation easement may be held by a "qualified organization" meaning the provincial government, a provincial government agency, a local authority including a municipality, or a body corporate that is a registered charity under the Income Tax Act that is constituted to hold conservation property interests and meets other conditions set out in the legislation. Given the array of entities that may hold a conservation easement, a municipality might consider whether its policy objectives or interests can be better met by some entity other than the municipality holding the interest. For example, a municipality may be satisfied if a land trust such as the Nature Conservancy holds a conservation easement that is negotiated in the context of a subdivision application. Then, the Nature Conservancy and not the municipality would have the responsibility to monitor and enforce the agreement, which could save the municipality money and free up person-power. ${ }^{86}$ As well, as mentioned earlier, a conservation easement may be modified or terminated by written agreement of the parties registered on title. This means that if

Local Government Act, R.S.B.C. 1996, c. 323, s. 305.2, as rep. by Community Charter Transitional Provisions, Consequential Amendments and Other Amendments Act, 2003, S.B.C. 2003, c. 52, s. 249. EPEA, supra note 9, s. 22(7).

Supra note 9, s. 219(9).

Property Law Act, R.S.B.C. 1996, c. 377, s. 35.

Note that the EPEA, supra note 9, s. 22(3), enables the grantor to designate a qualified organization other than the grantee to act as an additional enforcer, so that the designated qualified organization alone enforces or the designated qualified organization and the grantee enforce the agreement. Thus, with the blessing and designation by the grantor, an Alberta municipality could have a hand in enforcing even if it is not the grantee. 
the municipality is the holder of a conservation easement, it may terminate it by agreement with the original grantor or a successor in title. So, for example, if a future council wishes to undo a conservation easement it might be able to do so. This potential might be unpalatable to the public or persons interested in a particular subdivision or other process where a municipality is considering holding a conservation easement. A way to avoid this is to negotiate for some qualifying organization, other than the municipality, to hold a conservation easement.

\section{Transfer of DeVelopment Credit Programs and CONSERVATION EASEMENTS AND SIMILAR INSTRUMENTS}

\section{A. About Municipal Transfer of Development Credit Programs}

Although it is only possible to provide a scant description of such programs in this article, the author wishes to point out the potential for using conservation easements and similar instruments in the context of a municipal transfer of development credit (TDC) program. The author has discussed TDC potential in Alberta at length elsewhere. ${ }^{87}$

TDC programs provide a method of preserving rural landscape or urban areas by permitting the transfer of development potential from one area and conferring it on another. The owner of the restricted parcel receives development potential credit, which may be sold and used by a purchaser to increase development potential on another parcel more suitable for development, all in accordance with the TDC program. Unlike traditional zoning, TDC programs are designed to enable compensation for a landowner for the loss of development potential to carry out municipal preservation policies. The concept has been hailed as an "innovative way to accommodate both preservation interests and development interests." ${ }^{88}$

A typical TDC program involves transferring development potential from one parcel of land to another parcel of land in accordance with municipal plans, policies and by-laws. "Development potential” means the difference between existing land use and potential land use as allowed by and set out in applicable local land use by-laws and municipal plans. The parcel from which development potential is transferred is the "sending parcel." The parcel that receives the development potential is the "receiving parcel.” For example, if a land use by-law allows one single family residence per titled parcel in a given land use zone, a TDC program could give a landowner who holds four undeveloped titled parcels in the zone four development credits. The landowner may transfer the credits for value. Appropriate legal instruments secure restrictions on development in the sending parcel, such as conservation easements or restrictive covenants.

In the U.S., where TDC and [transfer of development rights] programs are common, the transfer normally is done in one of two ways. The first is on a market model. Here the holder of credits sells them to a willing purchaser at whatever price the market will bear. The municipality is not involved in the transaction. The second is a more regulated model. Here the holder of credits transfers them to a broker who arranges for ultimate sale. The broker could be the municipality or some other entity approved by the municipality. On either model, the purchaser can

87 This portion of the article is based on Arlene J. Kwasniak, “The Potential for Municipal Transfer of Development Credits Programs in Canada” (2004) 15 J. Envtl. L \& Prac. 47 [Kwasniak, “Credit Programs"].

88 Tom Daniels \& Deborah Bowers, Holding Our Ground: Protecting America's Farms and Farmland (Washington, D.C.: Island Press, 1997) at 171. 
use the credits in a receiving zone, identified in municipal plans and by-laws, subject to any required change of zoning, and subdivision and development processes. On either model, appropriate legal instruments secure development restrictions on sending parcels. ${ }^{89}$

Although the MGA does not expressly authorize TDC programs, in the author's view, a properly constructed TDC program is within municipal authority. ${ }^{90}$ Assuming this to be the case, there is an important role for conservation easements and similar instruments in a TDC program, at least in Alberta.

\section{B. A ROLE FOR CONSERVATION EASEMENTS AND SIMILAR INSTRUMENTS AND LIMITATIONS}

Conservation easements should meet some needs of a TDC program to secure development restrictions on sending parcels. Provided that legislation authorizing conservation easements in a province enables municipalities to hold them, a municipality could use conservation easements as part of a TDC program to secure development restrictions on sending parcels.

Although conservation easements might be appropriate to secure development limitations on sending parcels, in some situations they may not be suitable. A main reason concerns limitations on the purposes for conservation easements. In Alberta, conservation easements may only be granted for the specific purposes set out in that authorizing legislation, which were set out earlier in this article. Recall that under the $E P E A$, conservation easements were meant to protect natural landscapes and their components and not human created landscapes such as agricultural or heritage areas. However, where it is not appropriate to use a conservation easement to secure development restrictions, it may be possible to use other legal instruments. One possibility is a restrictive covenant discussed in Part II of this article. The municipality, however, must be sure that the common law conditions for a valid restrictive covenant have been met. Another is a condition or covenant under the Historical Resources Act. ${ }^{91}$ Most Canadian provinces have comparable legislation ${ }^{92}$ and definitions of historic or heritage resources typically are fairly

$89 \quad$ Kwasniak, “Credit Programs,” supra note 87 at 50.

90 The argument for this conclusion is set out in ibid.

$91 \quad$ R.S.A. 2000, c. H-9.

92 Starting from the west, the Local Government Act, supra note 82, s. 966, authorizes a local government, by bylaw, to enter into a heritage revitalization agreement with the owner of heritage property. The Alberta Historical Resources Act, ibid., s. 29, authorizes a landowner to enter into a "condition or covenant" with a municipality relating to the preservation or restoration of any land or building. Sections 26-27 also contain provisions for a municipality to a designate historical resources. The Saskatchewan Heritage Property Act, S.S. 1979-80, c. H-2.2, ss. 3, 28(f), 59, authorizes a landowner to enter into an "easement or covenant" with a municipality relating to the protection of "heritage property." Sections 2(k.2) and 11(1)(a) also provide for municipal council’s designation of Municipal Heritage Property. Manitoba's The Heritage Resources Act, C.C.S.M., c. H39.1, s. 21, enables owners to enter into heritage agreements with municipalities. The Ontario Heritage Act, R.S.O. 1990, c. O.18, s. 10(1)(b), authorizes a landowner to enter into "agreements, covenants and easements" with a municipality for the conservation, protection, and preservation of heritage of Ontario. The New Brunswick Historic Sites Protection Act, R.S.N.B. 1973, c. H-6, s. 2.1(1), authorizes the minister responsible for administration of the Act, or any other person if the easement or covenant is approved by the minister, to enter into an easement or covenant with respect to a historic site with the owner of the land on which the site is located. The Nova Scotia Heritage Property Act, R.S.N.S. 1989, c. 199, s. 20, authorizes a municipal council to enter into an agreement with the owner of "municipal heritage property" in a municipality regarding the use, preservation, or protection of the property. The Prince Edward Island Heritage Places 
broad. For example, the Alberta Historical Resources Act defines "historic resource” to include a "work of nature or of humans that is primarily of value for its palaeontological, archaeological, prehistoric, historic, cultural, natural, scientific or esthetic interest including, but not limited to, a palaeontological, archaeological, prehistoric, historic or natural site, structure or object."93 Section 29 enables the Minister (currently Tourism, Parks, Recreation, and Culture), the council of a municipality, the Alberta Historical Resources Foundation, or a historical organization approved by the Minister, to enter into a “condition or covenant” with a landowner to protect a historical resource. Once registered at the Land Titles Office, the agreement runs with the land notwithstanding the absence of a dominant tenement. ${ }^{94}$

\section{CONCLUSION}

Conservation easements can play a vital role in the protection of, as Leopold would say "wild things." 95 Without them, many natural landscapes would have given way to glass, concrete, and stone. With them, natural systems and the living beings that are part of them can more easily continue to be part of the Canadian landscape. This article has explored the values of conservation easements, pointed out shortcomings and limitations, and has provided cautions regarding their use. The article paid particular emphasis to the use of conservation easements by municipalities. Conservation easements are not perfect tools to enable landowners and governments to realize and maintain conservation objectives, but they do without doubt facilitate the realization and maintenance of many such objectives.

Protection Act, R.S.P.E.I. 1988, c. H-3.1, s. 10(1), enables a conservation or heritage organization approved by the Minister to enter into an agreement with the owner of property of heritage significance. The Act does not define "conservation or heritage organization" and there is nothing specific in the legislation that would preclude a municipality or municipal agency from constituting such an organization. As well, s. 10(1) of the Act states that ss. 11(3)-(7) of the Museum Act, R.S.P.E.I. 1988, c. M-14, applies to such an agreement. Section 11(6) of the Museum Act enables such an agreement to be assigned to a body corporate with similar objects. 